\title{
ARTICLES
}

Submitted 10.25.2020. Approved 05.18.2021

Evaluated through a double-blind review process. Guest Scientific Editor: Mário Aquino Alves

Original version | DOI: http://dx.doi.org/10.1590/So034-759020220207

\section{THEORETICAL-METHODOLOGICAL FOUNDATIONS AND PRACTICAL SYSTEMATIZATION OF SOCIOLOGICAL DISCOURSE ANALYSIS}

\author{
Fundamentos teórico-metodológicos e a sistematização prática da análise sociológica do discurso \\ Fundamentos teórico-metodológicos y la sistematización práctica del análisis sociológico del discurso
}

Katiuscia Schiemer Vargas ${ }^{1}$ | katiuscia.schiemer@gmail.com | ORCID: 0000-0002-3872-7972

Gilnei Luiz de Moura² | mr.gmoura.ufsm@gmail.com | ORCID: 0000-0003-4359-0365

1Universidade Federal do Pampa, campus Sant'Ana do Livramento, Sant'Ana do Livramento, RS, Brazil

¿Universidade Federal de Santa Maria, Departamento de Ciências Administrativas, Programa de Pós-Graduação em Administração, Santa Maria, RS, Brazil

\begin{abstract}
The objective of the paper is to present the theoretical and methodological foundations of sociological discourse analysis (SDA) and to demonstrate the practical application of its procedural basis by way of an exemplary case that has as its theme the culture of devotion to organizations. The development of a practical SDA plan is a constructive and incremental process and its paths are outlined as procedures under development. There is no general and/or rigid rule on what procedures are necessary for achieving the research objectives; the contextualizing interpretation of the discourses will determine the practice. The use of SDA as an analytical lens enabled us to explore the internal dimensions of the discourse, considering the social reality in which it is produced and providing an understanding of the culture of devotion through the senses and meanings that are constructed by the workers of the company we studied.
\end{abstract}

KEYWORDS | Sociological discourse analysis, research method, qualitative social research, qualitative analysis, culture of devotion.

\section{RESUMO}

O objetivo do artigo é apresentar os fundamentos teórico-metodológicos da Análise Sociológica do Discurso (ASD) e demonstrar a aplicação prática da sua base procedimental por meio de um caso exemplificador que tem como tema a cultura de devoção às organizações. O desenvolvimento do plano prático de ASD é um processo construtivo, incremental e tem seus caminhos delineados à medida que os procedimentos vão sendo desenvolvidos. Não há regra geral e/ou rígida sobre quais procedimentos serão necessários para a consecução dos objetivos da pesquisa; o que determinará a sua prática é a própria interpretação contextualizadora dos discursos. Em conclusão, o uso da ASD como lente analítica permitiu penetrar nas dimensões internas do discurso, considerando a realidade social em que ele é produzido, e proporcionou a compreensão da cultura de devoção por meio dos sentidos e significados construídos pelos trabalhadores da empresa estudada.

PALAVRAS-CHAVE I Análise Sociológica do Discurso, método de pesquisa, pesquisa social qualitativa, análise qualitativa, cultura de devoção.

\section{RESUMEN}

El objetivo del artículo es presentar los fundamentos teóricos y metodológicos del análisis sociológico del discurso (ASD) y demostrar la aplicación práctica de su base de procedimiento a través de un caso ejemplar que tiene como tema la cultura de la devoción a las organizaciones. El desarrollo del plan práctico del ASD es un proceso constructivo e incremental y se delinean sus caminos a medida que se desarrollan los procedimientos. No existe una regla general y/o estricta sobre qué procedimientos serán necesarios para lograr los objetivos de la investigación; lo que determinará su práctica es la interpretación contextualizadora de los discursos. En conclusión, el uso del ASD como lente analítica permitió penetrar las dimensiones internas del discurso, considerando la realidad social en la que se produce, y brindó una comprensión de la cultura de la devoción a través de los sentidos y significados construidos por los trabajadores de la empresa estudiada.

PALAVRAS CLAVE / Análisis sociológico del discurso, método de investigación, investigación social cualitativa, análisis cualitativo, cultura de la devoción. 


\section{INTRODUCTION}

Qualitative social research, as a reflective and contextual process, has the function of reconstructing the researched reality by interpreting its objective and subjective aspects; it is not only about describing punctual social phenomena and their external relations, but also making sense of and attribute meaning to human behavior and significant actions to the set of actors involved (Alonso, 1998).

For this, there are several approaches which a researcher could take to access, unveil and interpret reality, or even, specifically, their object of research. Nevertheless, numerous aspects are involved in the definitions concerning the analytical process and these, besides being able to reconstruct the field of social forces that gave rise to the research, must meet the objectives of the research (Ortí, 2014).

In the field of Organizational Studies, in addition to those themes that discuss the dynamics of organizations, their social, political, economic, ideological and psychological interfaces and their effects on individuals and society from the critical-reflexive perspective, the paradigmatic, epistemological and theoretical matrices of the field demand the development of interpretative research into the senses and meanings that allows us to understand the social reality being studied. To do this, it is necessary to get close to the "methodologies - both for the collection and analysis of empirical material - originated and constructed in sociology" - that is, more of a multidimensional amplitude tradition (subject-group-organization and society) - that can be presented as alternatives to the standard research approaches that are already widely practiced in the field (Godoi, Mastella, \& Uchôa, 2018, p. 35).

In this sense, it seems that, for this and other research fields that seek to evoke reflexivity and criticism, unveiling the controversies surrounding the legitimization of power relations and structures and the maintenance of certain social orders, the Madrid School of Qualitative Social Research's sociological discourse analysis (SDA), the Spanish tradition of social qualitative research and all of its epistemological, theoretical and technicalmethodological apparatus, would seem to be an appropriate framework to use. SDA tries to understand the motivations and reconstruct the meanings of the discourses by considering their social context and their historicity (Alonso, 1998; Godoi, 2010; Godoi, Coelho, \& Serrano, 2014).

In trying to historically depict the origins and the theoretic-epistemic perspectives of SDA, it is clearly observed its interdisciplinary roots - linguistics, semiotic, literary studies, anthropology, sociology, communication theory, social psychology and communication -, its epistemological pluralism, its interdisciplinarity and fragmentation in several schools and tendencies. For example, the main authors in SDA, who are representatives of critical sociology in opposition to the instrumental formalism of empirical sociology, can be allocated to at least three generations (Godoi, Coelho, \& Serrano, 2014).

As representatives of the first generation, there is Jesus Ibáñez (Ibáñez, 2003, 2010), who constituted the nucleus of the Spanish school of qualitative investigation and of SDA, and Alfonso Ortí (Ortí, 1986, 2010), both considered as main mentors of the method, in addition to Angel de Lucas (De Lucas \& Ortí, 1995). The second generation, which systematized SDA, is represented especially by Luiz Enrique Alonso (Alonso, 1998), Fernando Conde (Conde, 2009), the last a contemporaneous highlight in SDA research, as well as Jorge Ruiz Ruiz (Ruiz Ruiz, 2009) and Enrique Martín Criado (Criado, 2013). In turn, in the third generation, the main representatives are Araceli Serrano and Ângel Gordo, especially with their work Gordo and Serrano (2008), in which they innovated, even if revisiting some authors from the second generation, especially Conde (2009), while trying to adapt the SDA application to other themes, different from the one traditionally studied by the precursor authors.

In Brazil and in the field of organizational research, SDA is still a little used option, and besides theoretical studies - Godoi (2005), Godoi (2010); Godoi, Coelho and Serrano (2014) - developed with the purpose of bringing 
the perspectives of SDA and Organizational Studies closer, there are few practical works adopting the method. Prior to this study, only two theses which use SDA (Coelho, 2012; Mastella, 2015) and one using Sociological Discourse Analysis (SDA) (Uchôa, 2017, which originated Godoi \& Uchôa, 2019) were developed in the country, and from the some papers were originated with exemplifying cases of its practical application (Coelho, Godoi, \& Coelho, 2015; Godoi, Mastella, \& Uchôa, 2018; Soares \& Godoi, 2017).

It is a fragment of a wider research that approach the theme of the devotion culture in organizations, adopting SDA as theoretical-methodological support to access and analyze the reality being studied. Specifically, the moment of the research that had the objective of describing the context of the devotion culture was selected, emphasizing the elements that compose and characterize it.

The culture of devotion comprises a reality of extreme involvement of the worker to the precepts of the organization, where values, beliefs, habits, objectives and, mainly, its ideology are unquestionably worshiped; questions are renounced and a deified and sacred/consecrated symbolic universe is legitimized. In this sense, in order to understand it, it is necessary to evidence and observe practical aspects as well as symbolic aspects, crossing the concrete and abstract spheres, which, in turn, requires a scrutinizing attitude and look towards its elements and, overall, a reflexive, critical stance, guided by and for subjectivity. This demand adheres to the theoretical and methodological presuppositions of SDA.

Some studies (Collins \& Porras, 1995; Fossá, 2003) have suggested evidence of the expression (or not) of a devotion culture, and attributed its manifestation in organizations to different processes. The central elements that compose or represent evidence of a devotion culture, however, have not been unanimously agreed upon in studies on the subject.

Considering this, the relevance of this article is especially supported by the approximation of SDA with Organization Studies and research in Administration. It demonstrates the practical application of the method in an empirical study, and adds to the studies and the group of researchers who are working to consolidate the Brazilian SDA School. Even though it is not its focus, the article helps magnify devotion culture studies in organizations, which are still at an incipient stage, and in need of conceptual definitions and empirical investigations that explore from the formation mechanisms to how and why it is legitimated and maintained.

To this end, the paper is structured in five sections, the first being the introduction that presents sociological discourse analysis (SDA) and highlights the possibility of it being used in the field of organization studies. Briefly, and to put it in context since this is not the focus of the paper, it exposes the topic of an exemplary case, the culture of devotion. In the second section of the paper the theoretical-methodological foundations of SDA are set out in order to introduce the reader to the historicity and concepts underlying the method. Then, the third section presents the practical application plan of the method by means of the exemplifying case, while the fourth section presents the final considerations. The references used are presented in the fifth and final section of the paper.

\section{THE THEORETICAL-METHODOLOGICAL FOUNDATIONS OF SOCIOLOGICAL DISCOURSE ANALYSIS (SDA)}

The Sociological Discourse Analysis (SDA), linked to the Critical Qualitativist School of Madrid, consists of a pluralist approach which seeks to integrate social reality, facts, discourses and motivations (Ortí, 1986, 2010) and has as its parameter of analysis the social discourse (Alonso, 1998; Godoi, 2005, 2010; Godoi, Coelho, \& Serrano, 2014). 
It does not dissolve or suspend the subject, but rather seeks to recover it in the text so that the factors which generate actions and senses can be revealed (Alonso, 1998; Godoi, 2005, 2010; (Godoi, Coelho, \& Serrano, 2014).

There are multiple approaches to discourse analysis, among which the focus of interpretation can be on the word, the text or the context of the arguments. In order to demonstrate the range of perspectives of discourse analysis in a synthetic way, and to situate SDA in this list of discourse analysis and interpretation models, authors have suggested various levels of approach to the subject, such as those proposed by Ortí (1986), Alonso (1998) and Ruiz Ruiz (2009).

Initially, Orti (1986) proposed what he called the sociological construction process of reality, comprising three levels, regions or social structures: a) the field of fact: what happens and is done; b) the universe of discourse: what is said, expressed or signified; c) the realm of motivation: the reason for social interaction, its meaning, intentionality or purpose, and whether conscious or not.

In turn, Alonso (1998), one of the main theoreticians of the subject, proposed organizing it on three levels - or dimensions, as he recently called them (Alonso, 2012) - of approximation to discourse: informationalquantitative; structural-textual; and social-hermeneutical.

The informational-quantitative level has a perspective of analysis that is equivalent to classical content analysis, where the central unit of analysis is the word (Alonso, 1998). The text is reduced to a set of words, by which their symbolic meanings are excluded, and the social production process of their meaning precluded (Alonso, 1998; Godoi, 2010).

Covering most of the French discourse analysis tradition, the parameter of analysis of the second level of approximation to discourse, the structural-textual level, is the text, from which an internalist analysis of its excessively decomposed parts is carried out (Alonso, 1998). Essentially structuralist, that is to say, it strives to find the internal logic which gives meaning to the textual structure, the focus of this dimension is on linguistic analysis of the text, the materialization of the discourse, but without considering its insertion in the social context (Alonso, 1998).

The third level of approximation to discourse, the social-hermeneutic, which also called the social interpretation of discourse or the ethnolinguistics of discourse, where SDA resides, has as its core the internalist and externalist analysis of text. In other words, the text as a whole is considered in the context of the production of the discourse in order to understand how it was produced in a given social reality (Alonso, 1998; Conde, 2009).

Similar to Alonso's (1998) propositions, Ruiz Ruiz (2009) also proposes discourse analysis on three levels of approximation, called textual, contextual and sociological interpretation. The first level, textual, different from Alonso's (1998), focuses on content analysis and semiotic analysis, where discourse is characterized from enunciation; in turn, the contextual level already encompasses the understanding of discourse meanings by focusing on enunciation and considering situational and intertextual context; and finally, at the third level, sociological interpretation, the explanation of discourse is based on the dimensions of information, ideology and social product (Ruiz Ruiz, 2009).

According to Alonso (1998), SDA is only at the third level, the social-hermeneutical, while in Ruiz Ruiz's (2009) understanding, which is also shared by Ortí (1986) and Conde (2009), the SDA process must involve all levels.

Despite these apparent differences, the approaches of Alonso (1998) and Ruiz Ruiz (2009) are consistent when we take into consideration that the first and second levels are not sufficient for sociological analysis, which is in fact effective at the social-hermeneutical interpretation level in Alonso (1998), and at the sociological interpretation level in Ruiz Ruiz (2009) (Coelho, 2012). 
Of these, the third level of discourse approximation, the social-hermeneutical, is superimposed, in which intention consists in revealing the meanings linked to the organizational reality studied, and not only the pure analysis of the word strictly as enunciated and the internal structure of the text, characteristics of the analysis of classical content (first level) or semiotic analysis (second level).

At the social-hermeneutical level, the analysis exceeds the textual level. Discourse interpretation takes place through pragmatics, and focuses on the communication process, and on the interactions and conflicts between social groups considering the context in which they are situated (Conde, 2009). At the hermeneutical social level, SDA comprises a cyclical process between the materiality of the text, the context of discourse production and the characteristics of the social group to which the actors belong (Godoi, 2010; Godoi, Coelho, \& Serrano, 2014).

It is worth pointing out that, in practice, SDA leans both on the materialized text (internal textual analysis) and on the social subject and language as a space of power dispute, conflict and ideology (external textual analysis); it goes through the text and the context to achieve a social interpretation of the discourse. This is one of its main differences to other DA approaches that develop a purely internal analysis (for example, classic content analysis and most of the French DA school) or external analysis (for example, critical discourse analysis) (Godoi, Mastella, \& Uchôa, 2018).

This is, therefore, a contextual analysis of the arguments, called a socio-hermeneutical and pragmatic analysis (Alonso, 1998; Serrano, 2008), of contextualizing interpretation, where discourse and context are interconnected. We observe the dynamics of building discourse from social reality and edification of this through discourse (Godoi, Coelho, \& Serrano, 2014). For Ruiz Ruiz (2009), this is exactly the point that differentiates SDA from other approaches to discourse analysis: the connection between discourse and the social realities that surround it.

The central point of SDA is the contextualizing interpretation. It goes beyond the text and considers the pragmatics of discourse as revealing social practice. It goes beyond what is literally said (enunciation), manifest and explicit to identify the subject in the discourse (enunciation) and thus reveal what is implicit and latent (Alonso, 1998; Godoi, 2005, 2010). For Godoi (2005, 2009, 2010), a Brazilian SDA researcher, this approach to discourse analysis is what matters in organizational studies.

The context in SDA involves both objects and actions as well as habits, behavior, beliefs and other subjective and symbolic aspects of social reality (Alonso, 2002). It is the set of circumstances experienced, idealized or concerning a situational chaining, socio-cultural references that give meaning to discourse (Alonso, 1998; Godoi, 2010).

Discourse, in turn, does not comprise only words, but also the expression of social practices, relationship systems, and non-discursive practices in the literal sense. It is an expression of the consciousness of the subject who utters it (Alonso, 1998, 2012), a harbinger of ideological constructions, inconsistencies, contradictions and social fragmentations (Godoi, Coelho, \& Serrano, 2014; Ruiz Ruiz, 2009).

The SDA is praxeological, seeks to understand social processes within its structure and explain the meaning of the actions of social subjects. For Ruiz Ruiz (2014), sociologically analyzing discourse goes beyond pragmatics and addresses not only the interpretation of its explicit dimensions, but also its implicit and hidden intentions that are invariably present in social discourse.

In operational terms, SDA is far from being a technique that can be standardized or prescribed by means of a strict procedure manual. In its attempt to understand social phenomena, it is a dynamic, flexible interpretive process that must be adapted to each piece of research due to its peculiarities and the creativity of the researcher (Conde, 2009). 
As a guideline, Conde (2009) sought to systematize SDA theory - and was the first to do so - into practical procedures that are divided into phases that can serve as a primary guide for the researcher. For this purpose, as shown in Figure 1, the author proposes four major steps for its development that are subdivided into processes): 1) Initial Practical Works; 2) Interpretation Procedures; 3) Analysis Procedures, and 4) Complementary Procedures to Analysis and Interpretation.

Figure 1. Practical plan of SDA

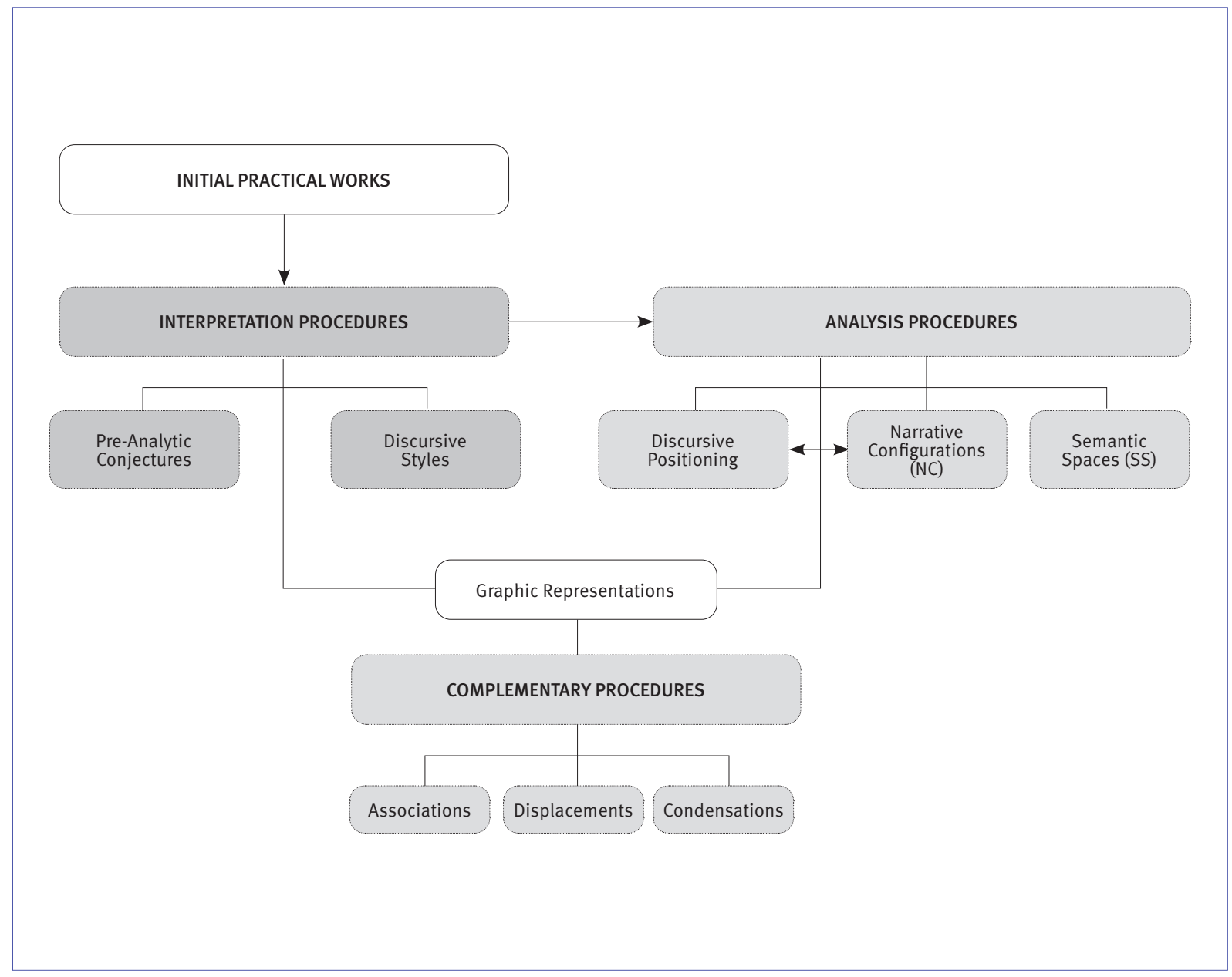

Source: Prepared by the authors.

Throughout the development of the practical SDA plan, graphic representations are used as visualization and ordering tools, and can be presented in different formats: frames, matrices, schematics, figures, among others, which are the responsibility of the researcher's own creativity (Conde, 2009; Godoi, Coelho, \& Serrano, 2014). Graphic representations are of paramount importance to the researcher in the process of creating and validating conjectures, for identifying the most relevant dimensions of the lines of analysis and interpretation, and allowing evidence of the evolution over time of discursive positions, narrative configurations and constructed semantic spaces to emerge. They also establish the contextual relationships of the concepts generated and, also, configure and analyze the systems of discourse (Coelho, 2012). 


\section{A PRACTICAL PLAN OF SOCIOLOGICAL DISCOURSE ANALYSIS (SDA): THE CASE OF THE CULTURE OF DEVOTION AT LIBERTY COMPANY}

The case used in this paper as an example is part of broader research whose general objective was to understand the processes involved in legitimizing and maintaining the culture of devotion and its intertwining with the reasons why workers become devoted to an organization. One of the specific objectives of this research, which was epistemically and methodologically designed in the field of critical organizational studies, was to describe the context of devotion culture by emphasizing the elements that compose and characterize it. This was the example used to demonstrate the use of SDA through an analytical lens. Adopting a qualitative and exploratory approach, this is an intrinsic case study carried out in a company in the Information Technology (IT) and Statistical Intelligence (SI) field. Its fictitious name is Liberty, which was chosen because it is representative of the phenomenon being studied.

Liberty, which was founded in 2001, is a leader in the anti-fraud market. It sells anti-fraud solutions to the retail market (with a focus on e-commerce, telecoms, financial services, direct sales and insurance), such as platforms/systems for analysis and decision-making with regard to the approval/reproval of orders (end consumer purchases), or fully managing the fight against fraud. At the time of the survey, it had 1.107 employees working at its headquarters in São Paulo/SP, Brazil. It also had eight employees (four Brazilians and four Americans) working in the United States (USA), where it installed an office in 2015 and began its process of internationalization.

To develop the research, the analytical corpus was composed of semi-structured interviews, carried out with workers in different discursive positions in order to obtain a panoramic view of the reality being studied, as indicated by Ruiz Ruiz (2009). A total of thirty workers were interviewed, ten from the "management" (M) and twenty from the "operation" (OP) organizational level.

The interviews were recorded in audio and at the end of each of them, perceptions, reflections, reminders and insights were recorded in a notebook, a support instrument for documenting the research process, which also contributes to the practical analytical development of the data oriented by SDA. The interviews were then transcribed in their entirety, and symbolic conventions were adopted to record the identity of the speaker (researcher and interviewee), interruptions, hesitations, non-grammatical classes, and even text formatting patterns.

In addition, direct, free observations were made, without the use of previously defined categories or observation scripts (Trivinõs, 2008) and carried out at all times when researchers were present at the company, focusing on practices, events, speeches, actions, attitudes and behaviors in daily work. The observations were used as a subsidy for the composition of the organizational context where the research was developed and to record the experiences in the field.

The practical SDA plan begins with the Initial Practical Works, which corresponds to the general and introductory tasks which precede the actual interpretation and analysis processes. It involves four main procedures that are detailed in Exhibit 1.

After the Initial Practical Works, we move on to the Interpretation Procedures, the second stage of the SDA practical plan, which is centered on two processes: the preparation of pre-analytical conjectures, and analysis of discursive styles.

The elaboration of pre-analytic conjectures, i.e., of the initial hypotheses, allows to compose a general sense for the text and direct the interpretation of the discourses to the objective of the research (Conde, 2009). By validating them, it is possible to verify their ability to integrate and explain the opinions, judgments, positions and debates of most of the research subjects, and comparison of the same with the objective of the research, 
when corrections and modifications can be made as necessary (Conde, 2009). The pre-analytical conjectures are gradually formulated during the analysis process and, when necessary, corrected and modified, thus obtaining analytical conjectures that highlight most of the positions and understandings of the research subjects.

\section{Exhibit 1. Initial practical works}

\begin{tabular}{|c|c|c|}
\hline \multicolumn{2}{|l|}{ PROCEDURE } & DESCRIPTION \\
\hline \multirow{3}{*}{$\begin{array}{l}\text { PREPARATION OF TEXT } \\
\text { ANALYSIS }\end{array}$} & $\begin{array}{l}\text { Tasks immediately after } \\
\text { fieldwork }\end{array}$ & $\begin{array}{l}\text { Identification of meaningful themes. } \\
\text { Elaboration of positioning maps to identify points of conflict (text and } \\
\text { image). } \\
\text { Registration of the first intuitions, sensations, ideas and conclusions } \\
\text { of the interviews. }\end{array}$ \\
\hline & Transcripts & $\begin{array}{l}\text { Literal transcription of the interviews. } \\
\text { Reading of the transcriptions accompanied by the audios. } \\
\text { Inclusion of comments, pauses, movements, movements, participants } \\
\text { during the interview. }\end{array}$ \\
\hline & & Preparation of the profile of the interviewees. \\
\hline \multirow{2}{*}{$\begin{array}{l}\text { PREPARATION OF THE } \\
\text { READING WORK }\end{array}$} & $\begin{array}{l}\text { Ordered reading of text } \\
\text { corpus }\end{array}$ & Creation of a provisional initial reading order for the interviews. \\
\hline & $\begin{array}{l}\text { Literal reading of the } \\
\text { text }\end{array}$ & $\begin{array}{l}\text { Reading and literal re-reading of the text, paying attention to changing } \\
\text { the usual way of reading. } \\
\text { Identification of clues generating peculiarities that lead to conjectures. }\end{array}$ \\
\hline \multirow{2}{*}{$\begin{array}{l}\text { DECOMPOSITION AND } \\
\text { INTEGRAL APPROACH TO } \\
\text { TEXTS }\end{array}$} & $\begin{array}{l}\text { Decomposition into } \\
\text { elementary units }\end{array}$ & $\begin{array}{l}\text { Analytical decomposition - elementary units of analysis (headings, } \\
\text { themes or categories of analysis or units of direction) for later } \\
\text { synthesis. }\end{array}$ \\
\hline & Full text approach & $\begin{array}{l}\text { Global and integral approximation to the text (integrative } \\
\text { approximation). }\end{array}$ \\
\hline \multicolumn{2}{|c|}{ GENERAL NOTES ON THE TEXTS } & $\begin{array}{l}\text { Characterization, classification and codification of contents; marking } \\
\text { expressions, insights, associations, hypotheses, important elements. }\end{array}$ \\
\hline
\end{tabular}

Source: Based on Conde (2009) and Godoi, Coelho, \& Serrano (2014). 
The culture of devotion is understood as a system of symbolic elements engendered through organizational practices which regulate and promulgate veneration, dedication and loyalty, the establishment of bonds and feelings of belonging, connection and identification. Workers are presented with symbolic and rational meanings to interpret and experience the differentiated and privileged world created through the institutionalization of the dominant ideology and the development of an organizational religiosity, both based on a cohesive disciplinary apparatus.

In this sense, understanding the culture of devotion starts with the social reality and interpreting its context. This involves the characteristics of the organizational scenario, the daily work, the practices that materialize and equip its existence and, finally, the elements which compose it and make it evident are described. To this end, the study carried out at Liberty initiated by describing in detail its cultural context, which was recorded from the experiences in the field and analyzed using the discourses of the thirty workers we interviewed. Specifically, in the context of the culture of devotion we observed:

- A relaxed, informal and welcoming environment, which allows everyone to express their own identity and makes its members feel part of something special;

- Personal involvement, establishing bonds and connections, creating a family atmosphere, which makes the company a home away from home, a space that mixes duty and pleasure;

- Daily work based on proposals of freedom, flexibility and relaxation, which is a combination, in the same space and time, of periods of intense work, moments of relaxation and a focus on personal issues;

- Integration events, moments of leisure and social activities between co-workers, actions aimed at the well-being, health, art and education of employees;

- $\quad$ Support groups and dialogues on personal issues, events to get the family into work, and programs for referring people to work in the company;

- Internal communication and endomarketing actions, engagement programs, policies and central processes in people management - recruitment, selection, socialization, training, development - that are imbued with meaning;

- $\quad$ Rigid selection process focuses on cultural alignment;

- $\quad$ Extensive and intense adaptation program for new employees;

- Training programs, of own creation, carried out within the company and directed at the core of the business;

- Offer and/or facilitate the realization of improvement courses aimed at the development of the professional;

- $\quad$ Events, rituals and celebrations, spaces for instituting their dogmas, disseminating their values and philosophies, and above all, cultural indoctrination.

From this composition and characterization of Liberty's cultural context, a Pre-Analytic Conjecture has emerged about the role of the cultural context in the process of maintaining the culture of devotion. The following graphic representation (Figure 2) presents the initial explanatory hypothesis. 
Figure 2. Pre-analytical conjecture - the role of the cultural context in maintaining the culture of devotion

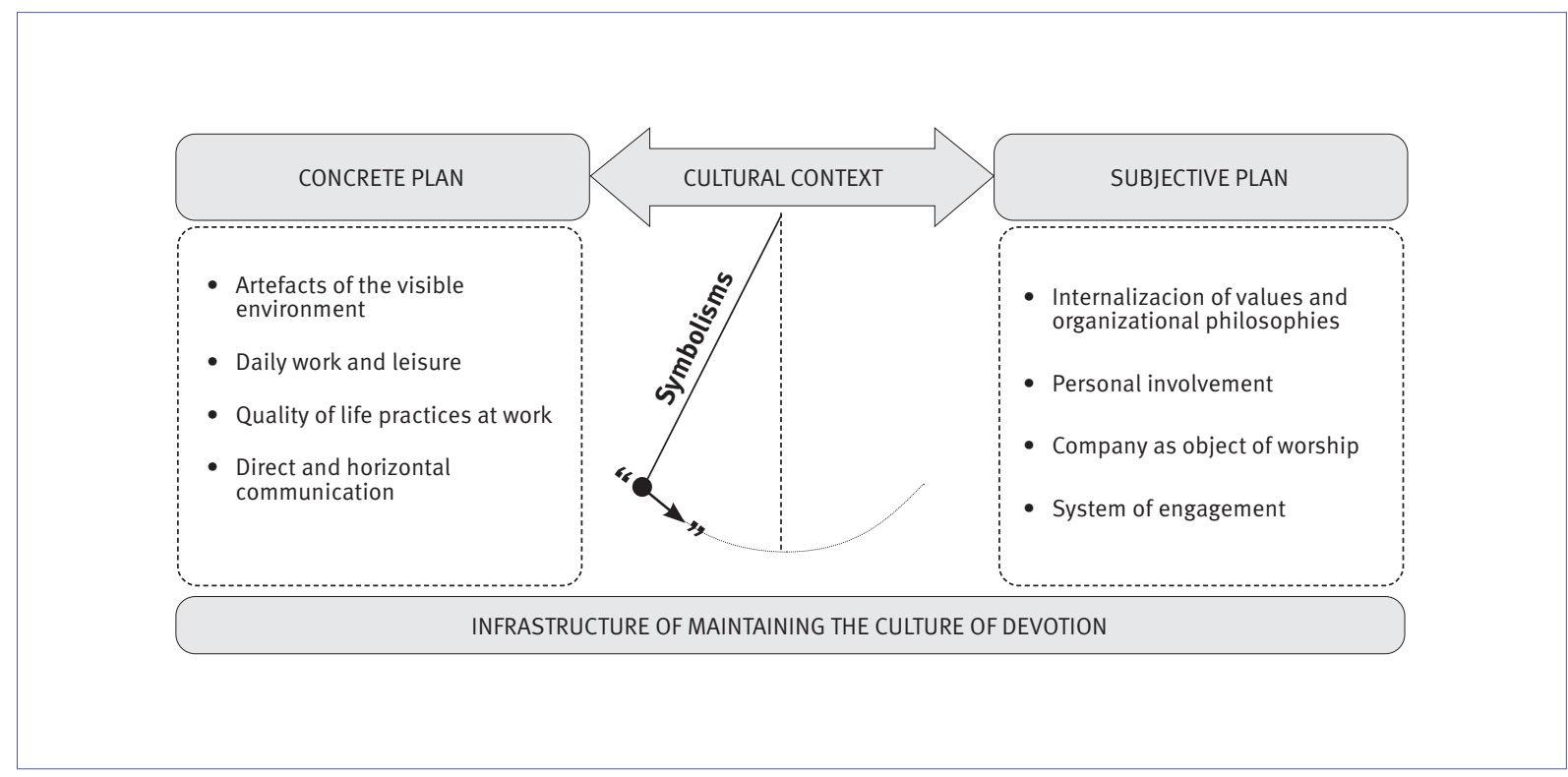

Source: Prepared by the authors.

The established Pre-Analytic Conjecture consisted in the understanding of the cultural context, characterized by a concrete plan and a subjective plan, as an infrastructure for maintaining the culture of devotion. The symbolisms that permeate the cultural context are constantly disseminated both in the scenario, in the organizational practices and strategies (concrete plan), and in the meanings worked by the company (subjective plan) and, in this way, objectively and subjectively ensure the subsistence of the culture of devotion.

Continuing the analytical process, we moved to the analysis of discursive styles - SDA Interpretation Procedure - which involves the recognition of the possible lines of conditioning of the research subjects. The conditionings can understand the general characteristics of the social group, given its insertion in a social and ideological structure, as well as the singular, biographical and attitudinal characteristics of the subject in relation to the social phenomenon studied (Conde, 2009).

In this sense, it was perceived that the visions, experiences and symbolisms absorbed from the cultural context are conditioned by the hierarchical level and sector in which the employee acts. In other words, the social positioning of the employee in the company directs their perceptions, experiences and interpretations of culture. The excerpts from the discourses of two interviewees belonging to the organizational levels of "management" (M) and "operation" (OP), respectively, demonstrate, as Conde (2009) suggests, the narrative styles and the most expressive ways of constructing discourses about the cultural context:

M_4 - Vice president: [...] I want my employees to think about the company all the time, just as I allow them to think about their personal lives when they are in the company.

OP_12 - Operational Sector: When I started working at Liberty and I got to know the culture, I saw the way to work and I saw what we do, I fell in love with it. This is very good, you work, I live in Poá, a small town here in São Paulo, it's far away, I take between two and two and a half from my home. São Paulo is 
very big, it's very big, it has traffic, the subway stops, so it takes a long time and that's why people say: Gee, what motivates you to spend two hours - a four or five hours a day round trip - driving? But it's very good, here is a family, time passes and I don't notice it.

The discourses of the "management" and "operation" interviewees reveal an interpretation of the cultural context that is permeated by a multiplicity of symbols that are linked to everything they experience in the company, from enjoying physical spaces, daily life, people management practices and policies, to how to relate to the work environment; all are imbued with meanings and subjectivities.

The main symbolisms latent in Liberty employees' discourses were the idea of "exchange", of a win-win relationship between the company and the employee, the feeling of "property", of being the owner of the company, which they called ownership, work with "purpose" and social value, and the establishment of intimate and strong "bonds" in the organizational environment, considering the company as a family, a home.

Then we move on to SDA Analysis Procedures, a stage in which a systematic analysis of the text is carried out through the analysis of discursive positions, narrative configurations and semantic spaces, as well as the process of relating narrative configurations and semantic spaces.

The analysis of the discursive positions is developed, initially, by the identification of the discursive fractions, in other words, of small positions of the subjects who, after, are grouped, giving rise to the discursive positions themselves (Conde, 2009). In the sequence, the analysis of the narrative configurations is mainly concerned with exposing the central axis of the message manifested in the discourse (Godoi, Coelho, \& Serrano, 2014), portraying, as far as possible, the latent meanings of the texts (Coelho, 2012).

When analyzing the discursive positioning - Who is the social subject who is speaking? Which social place is the subject talking about? - and the narrative configurations - What is being spoken about? How is the discourse organized? -, we found differences in the symbolism expressed in the discourses of the employees, who are mainly determined by their social positioning in the company.

Correlating concrete discourse with the social space and developing a sociological interpretation of the discourse, we verified that the views of Liberty's employees with regard to the cultural context are positioned between two poles, the idealistic and the strategic, which end up defining the narrative configuration of the symbols produced at these two poles.

The graphic representation expressed in Figure 3 demonstrates the discursive positioning and the narrative configurations of the cultural context. The horizontal axis of the graphic representation corresponds to the vision of the cultural context, from idealistic to strategic, and the vertical axis to the main symbolisms expressed in the discourses, also varying between idealistic and strategic. The subjects of the research are represented by gray blocks containing their identification acronym and the sector in which they work, and they have been distributed among the axes of the figure according to their vision of the cultural context and the predominant symbolisms in their discourse.

By distributing the subjects of the research on the axes of the graphic representation, three groups of discursive position and, consequently, of different perceptions were formed, characterized by their hierarchical level, and their relationship and/or proximity to the center of the business. Administration (1), Core (2) and Operational (3) compose groups that qualify the vision of the cultural context, create, interpret and, at the same time, disseminate symbolisms according to the conditions inherent to their social positioning. 
Figure 3. Discursive positionings and narrative configurations - cultural context

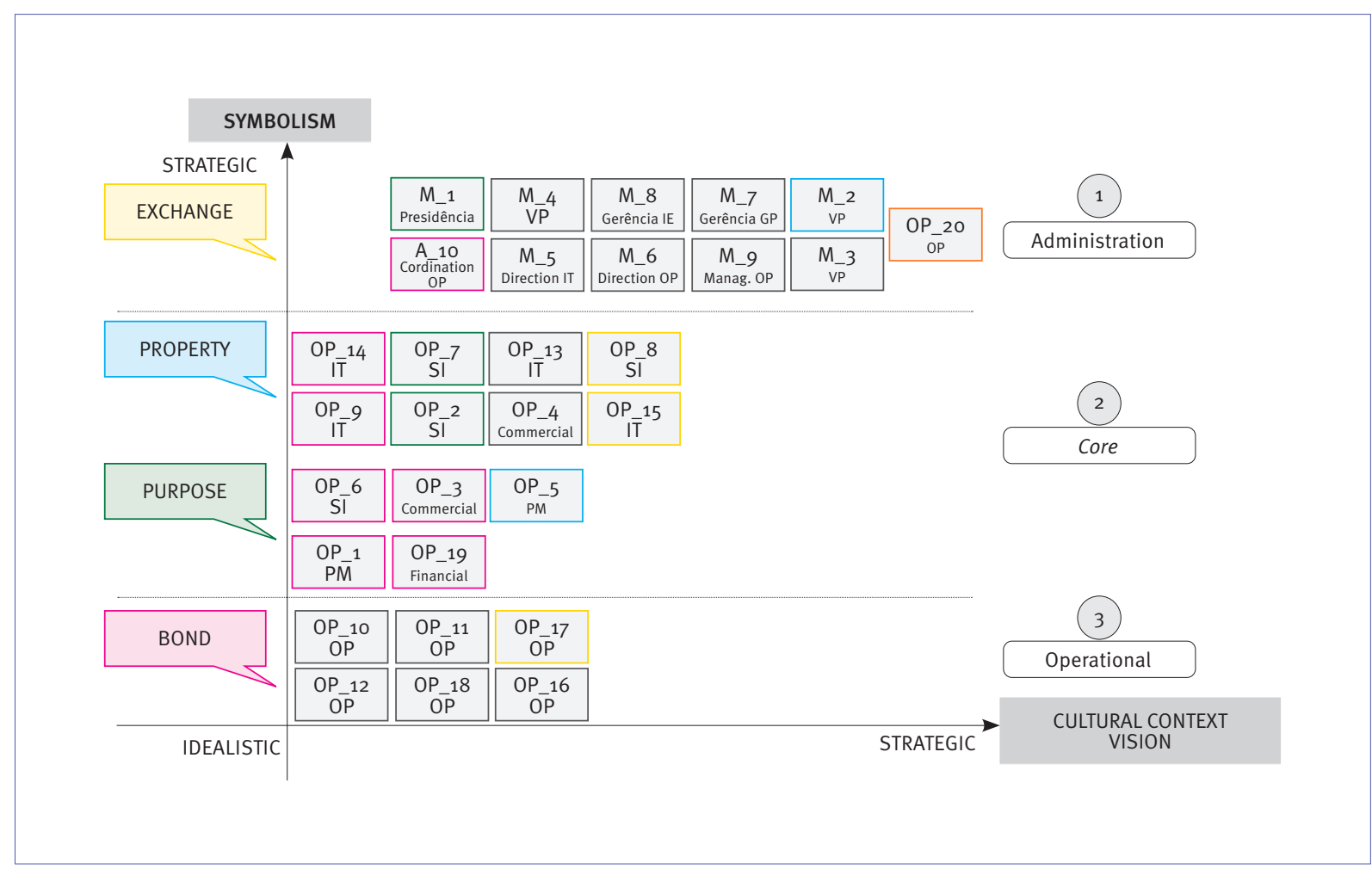

Source: Prepared by the authors.

Moving on to the third and last stage of the triad of SDA Analysis Procedures, we analyze the semantic spaces which, constituting a more internalistic analysis of the texts, focuses on two main elements: 1) analysis of the semantic attractors, in the other words, analysis of the main verbal and symbolic expressions which organize and configure the field of significations of each space; and 2) analysis of the discursive axes, which link one or the other semantic attractor, weaving the plot which relates one semantic space to another (Godoi, Coelho, \& Serrano, 2014).

When analyzing the semantic spaces - What is the meaning of what is said? What is at stake when speaking? - of the discourse of the interviewees from the Administration group, we found that the symbolism of "exchange" is predominant, and is, therefore, around the central discursive axis of the cultural context of Liberty.

For this group of interviewees, Liberty's cultural context is strategic in establishing a compensation mechanism between worker and company. "This welcoming environment makes you relax to work well [...]" (M_6 - Operational Director); "[...] it's actually an exchange, a win-win, right?! (M_7 - People Management Manager); "So, you have this freedom, but because you need to deliver a lot [...]" (M_9 - Operational Manager). These are some examples of the main verbal and symbolic expressions which organize and configure the field of meanings of the interviewees of this group about the cultural context of Liberty.

In general, by carrying out both an externalist analysis, considering perspectives and points of view, and an internalist analysis, focusing on content and concrete statements, what is revealed in the discourses of the interviewees of the group called Administration are teleological arguments that express as the purpose of the 
composition of the cultural context the expectation of rewarding the employee with development and good results, for themselves and, therefore, for the company.

About the discourses of the Core employees, as shown in Figure 3 when representing the narrative configurations, the main symbolisms identified were the sense of "ownership" and social "purpose" in the work they perform, the prevention of fraud. In addition to these central symbolisms, some highlighted the "bond" of intimacy established with the company and, to a lesser extent, the "exchange" between the company and workers regarding well-being at work and commitment to organizational objectives. In turn, the symbolisms mentioned in a prominent way by the subjects of the Operational group were the "bonds" that they establish with their colleagues, with the company and everything it represents in their lives, followed by an understanding of work with "purpose" and social value. Figure 4 graphically represents the semantic spaces emblematic of the discourses of the two groups, Core and Operational, in other words, it presents the main verbal materialities as well as contents which developed in the discourses of these subjects.

Figure 4. Semantic spaces - Core and Operational - cultural context

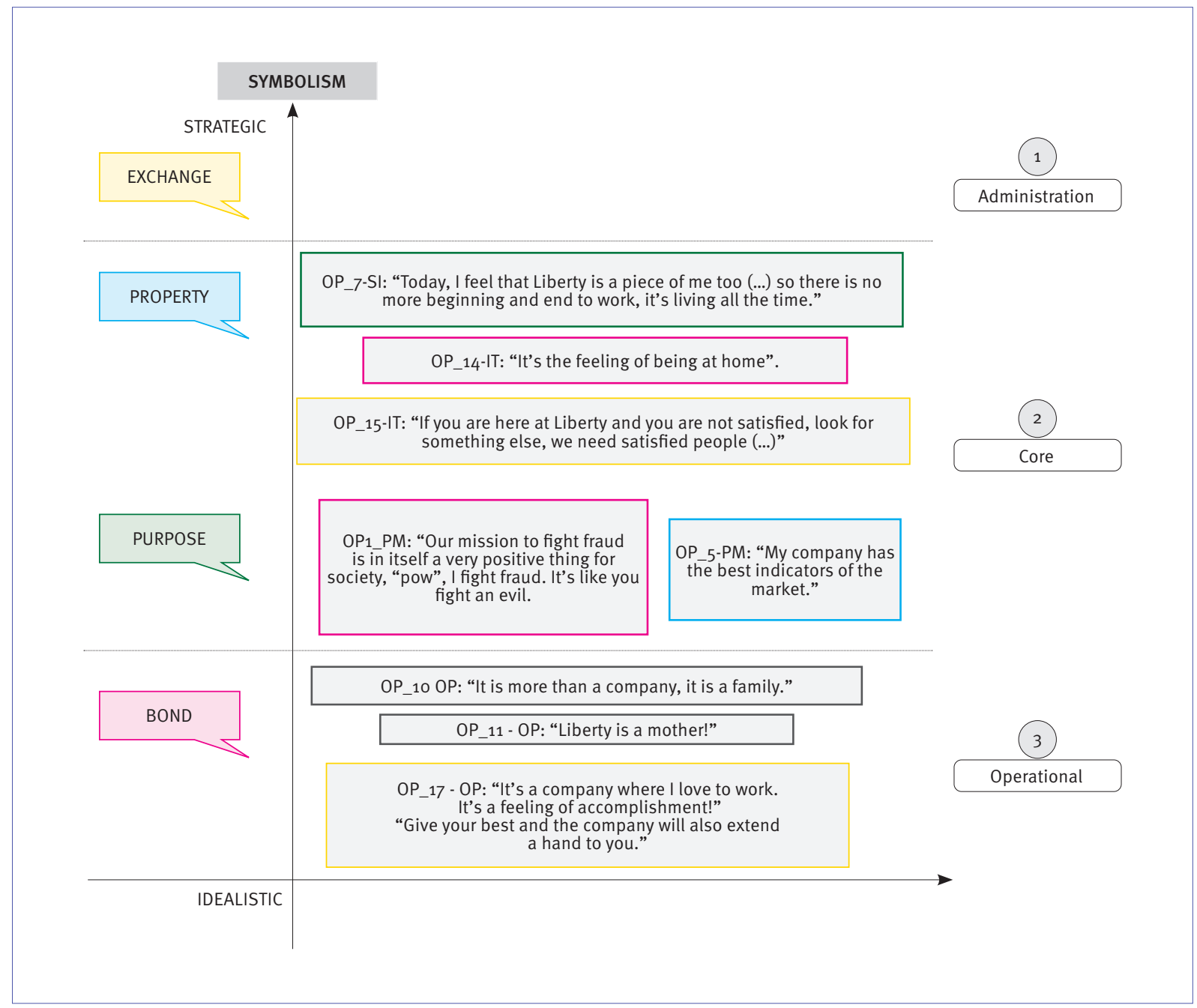

Source: Prepared by the authors. 
Several narrative and argument paths were developed throughout the discourses of the interviewees from the Core and Operational groups. It is easy to recognize, however, that the common thread of the discourse of both were the links established between the company and employees, and between employees.

In the discourse of the Core and Operational interviewees we also notice that all of the symbolisms that are produced and disseminated - ownership, purpose and bonds - are used as justifiers of the reality that results from the culture of devotion, which, at the same time, provides all this context that is interpreted as being beneficial, but that demands extreme involvement, giving, excellence and superiority and, thus, leads to continuous selfrecovery, with no separation between working and non-working time, and dominion over the plans of the workers who are unable to imagine themselves outside the company.

The cultural context of Liberty, at the same time, produces and disseminates different symbolisms at each organizational level, which are applicable to the social positioning of the employee in the company, for example, the feeling of property - ownership - is not a symbolism which reaches the operating employees. This is healthy for the maintenance of the culture of devotion, because what is relevant and significant for one reality may not be for the other, given their work context, life circumstances and relationships with work. For this, the intermediate leaders are important tools in maintaining the culture of devotion, because it would not help management to idealize values and a philosophy if there were no vectors to disseminate it. They represent the intersection between the poles naturally existing in organizations; company and employees, managers and workers.

Thus, by comparing the experiences of the field with the discourses of the research subjects, the Pre-Analytic Conjecture was adjusted and validated about the role of the cultural context as an infrastructure for maintaining the culture of devotion. For this purpose, the graphic representation called Figure 5 shows the Analytical Conjecture which characterizes the understanding about the process of maintenance of the culture of devotion.

Figure 5. Analytical conjecture - the role of the cultural context in maintaining the culture of devotion

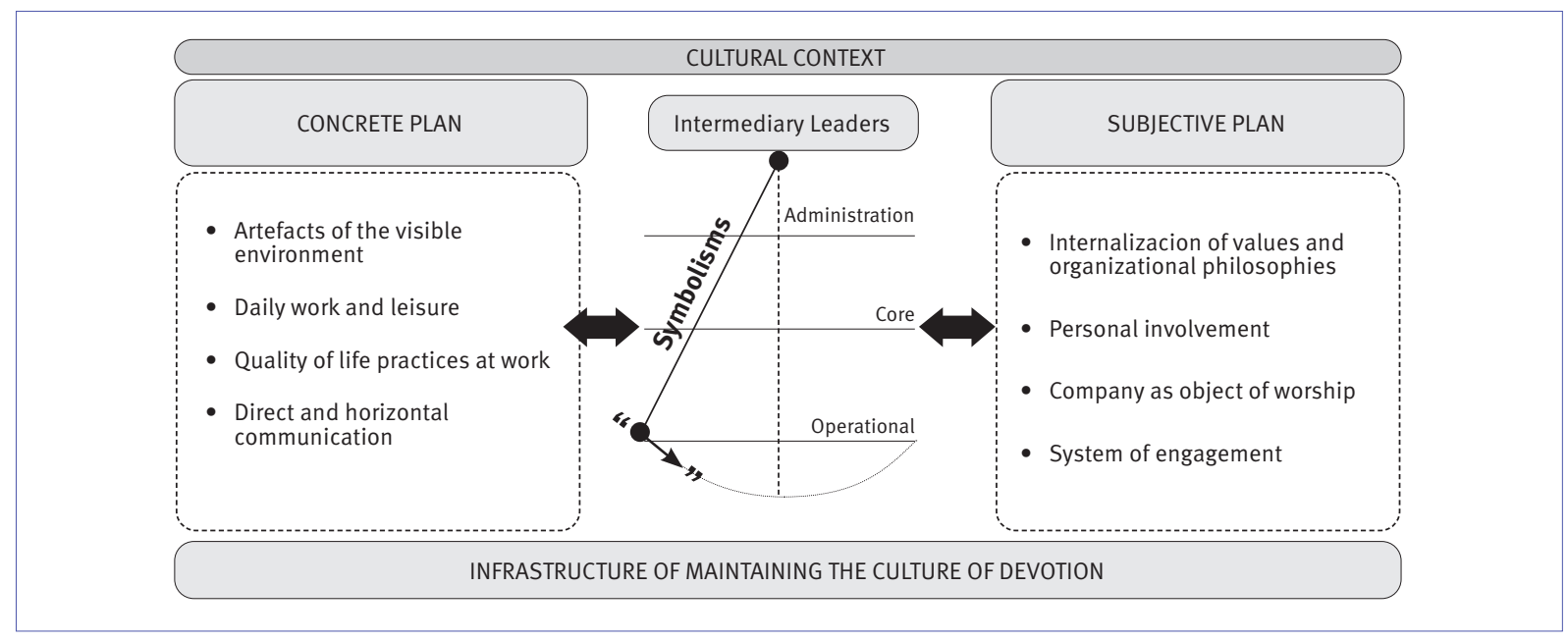

Source: Prepared by the authors.

The concrete plan (scenario, practices and organizational strategies) of the cultural context is the material, physical and objective representation of the culture of devotion, stimulating the creation of symbolisms which, synchronously, are disseminated with the support of intermediary leaders. The symbolisms produced and/or that reach each organizational level are different and are related, mainly, to the social positioning of the worker 
in the company. In turn, the subjective plan encompasses the meanings produced from the concrete plan and, above all, based on the symbolisms.

Finally, when concluding the demonstration of the practical application of the Sociological Discourse Analysis (SDA) procedural basis, it is worth reiterating that it is an analytical, constructive and incremental process. Therefore, the conclusions about the cultural context are recalled throughout the analysis of the other analytical dimensions of the broader study carried out addressing the theme of the culture of devotion. Moreover, it is important to point out that the method was not developed in the same way and following the same order in the following moments of the research, because, as already explained, it is not a rigid method, however, it is undertaken by the researchers guided in the achievement of the purposes of the research.

\section{FINAL CONSIDERATIONS}

Using an example case to present the theoretical-methodological elements and show the practical application of the procedural base of Sociological Discourse Analysis (SDA), this article brings contributions of thematic and, especially, methodological nature - main objective.

When carrying out any study that addresses the subject of the culture of devotion, it is necessary to adopt an approach that allows the processes, directions and meanings that are built up and shared by the workers who are part of this symbolic universe to be revealed. In view of this, the sociological discourse analysis of the Madrid School of Qualitative Social Research, the Spanish tradition of qualitative social research, was considered to be an appropriate reference.

The adoption of SDA, not only as an analytical option for the empirical material, but also as a positioning vis-à-vis the phenomenon being studied, but above all as an approach and way of conducting the research as a whole, enables academics to penetrate the internal dimensions of discourse, and go beyond the manifested plan and consider the social reality in which it is produced.

To this end, the first procedures developed were the Initial Practical Works, followed by the Interpretation Procedures and the Analysis Procedures. At the same time, some practical steps of the Complementary Procedures were developed, specifically, analysis of associations and condensations. There were no analyses of displacement, i.e., changes in theme and content, expressions indicating a defensive position, conflict, brake, censorship or repression (Conde, 2009), as these were not observed in the discourses of the interviewees. It is important to highlight that Complementary Procedures have their origin based on psychoanalytical theories (Godoi, 2018) requiring the researcher's specific knowledge to identify and interpret these mechanisms in depth.

In this sense, with regard to the contributions to the theme of the exemplary case, after developing the practical plan of SDA to describe the context of the culture of devotion emphasizing the elements which compose and characterize it, it was verified that the cultural context ends up being configured as an inescapable substratum of the culture of devotion, because through the frequent pulverization of symbolisms in concrete and observable, subjective and intangible instances, it surrounds the conscious and the unconscious of the employee. Therefore, the cultural context not only represents and echoes the message which the company wants to transmit, but also enables the institutionalization of an infrastructure to maintain the culture of devotion over time.

It is worth reiterating, as Conde (2009) stresses, that the analysis process does not constitute a standardized didactic sequence, or one that is cemented in a plan to be mechanically followed. On the contrary, not all the 
steps are necessary in all research, and it is up to the researcher to verify their relevance and appropriateness to the purposes of the research. . In the broader study of which the exemplifying case is part, for instance, it was necessary to apply the complete practical plan of SDA other times, and the order of the procedures did not necessarily occur in the same way as presented here, however, according to the perceptions of the researchers with regard to the needs for achieving the general objective of the research.

Furthermore, it is important to point out that, given the purpose of demonstrating the practical application of the Sociological Discourse Analysis (SDA) procedural basis, the focus of this methodological paper was not exactly to deepen the results and discussions about the culture of devotion, having it only as an example case and background to elucidate the use of the method.

Finally, regarding the methodological contributions, considering that SDA is still scarcely applied in empirical research in the field of Organizations Studies and Management it is expected that this article might aid the practice of beginner researchers and encourage its use in qualitative investigations, especially in critical studies to which SDA adheres, as it is not concerned only with the visible sphere of language and seeks to penetrate the aspects that are not expressly manifested by the subjects.

\section{REFERENCES}

Alonso, L. E. (1998). La mirada cualitativa en sociología. Madrid, España: Fundamentos.

Alonso, L. E. (2002). Los mercados lingüísticos o el muy particular análisis sociológico de los discursos de Pierre Bourdieu. Revista de Estudios de Sociolingüística, 3(1), 111-132. Retrieved from https://dialnet.unirioja.es/revista/538/A/2002

Alonso, L. E. (2012). Sociedad y discurso o discurso sin sociedad: El debate postestructuralista. Encrucijadas - Revista Crítica de Ciências Sociales, (4), 7-25. Retrieved from https://recyt. fecyt.es/index.php/encrucijadas/article/view/78873

Coelho, A. L. A. L. (2012). Construção do discurso da sustentabilidade: Uma prática de análise sociológica do discurso no campo organizacional (Tese de Doutorado em Administração e Turismo, Universidade do Vale do Itajaí [UNIVALI], Biguaçu, SC).

Coelho, A. L. A. L., Godoi, C. K., \& Coelho, C. (2015). Análise sóciohermenêutica do discurso da sustentabilidade a partir de materiais visuais. Revista de Administração Contemporânea - RAC, 19(5), 649-670. doi: 10.1590/1982-7849rac2015150032

Collins, J. C., \& Porras, J. I. (1995). Feitas para durar: Práticas bem-sucedidas de empresas visionárias. Rio de Janeiro, RJ: Rocco.

Conde, F. (2009). Análisis sociológico del sistema de discursos. Madrid, España: Centro de Investigaciones Sociológicas.

Criado, E. M. (2013) Mentiras, inconsistencias y ambivalencias: teoría de la acción y análisis de discurso. In: SEMINARIO PERMANENTE DE SOCIOLOGÍA: Jornadas de análisis de discurso en ciencias sociales, 2013, Sevilla. Anais... Sevilla, Andalucía, España.
Lucas, A., \& Ortí, A. (1995). Génesis y desarrollo de la práctica de grupo de discusión: Fundamentación metodológica de la investigación social cualitativa. Investigación y Marketing, 47, 6- 9.

Fossá, M. I. T. (2003). A cultura de devoção nas empresas familiares e visionárias: Uma definição teórica e operacional (Tese de Doutorado em Administração, Universidade Federal do Rio Grande do Sul [UFRGS], Porto Alegre, RS).

Godoi, C. K. (2005). Análise do discurso na perspectiva da interpretação social dos discursos: Uma possibilidade aberta aos estudos organizacionais. Gestão.Org - Revista Eletrônica de Gestão Organizacional, 3(2), 90-105. Retrieved from https://periodicos.ufpe.br/revistas/gestaoorg/article/ view/21574/18268

Godoi, C. K. (2009). A perspectiva da interpretação social dos discursos: Uma prática de análise dos discursos motivacionais na aprendizagem com base nos atos da fala, enunciação e contexto. In A. P. Carrieri, Análise do discurso em estudos organizacionais (pp. 131-152). Curitiba, PR: Juruá.

Godoi, C. K. (2010). Perspectivas de análise do discurso nos estudos organizacionais. In :C. K. Godoi, R. Bandeira-deMello, \& A. B. Silva (Orgs.), Pesquisa qualitativa em estudos organizacionais: Paradigmas, estratégias e métodos (2 $2^{\mathrm{a}}$ ed., pp. 375-401). São Paulo, SP: Saraiva.

Godoi, C. K. (2018). Indicações bibliográficas. Análise Sociológica do Discurso e grupo de discussão: Práticas da tradição espanhola de pesquisa qualitativa. RAE-Revista de Administração de Empresas, 58, 585. Retrieved from https://rae.fgv.

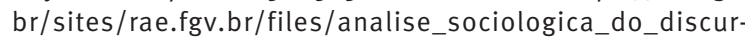
so_e_grupo_de_discussao_praticas_da_tradicao_espanhola_de_pesquisa_qualitativa.pdf 
Godoi, C. K., Coelho, A. L. A., \& Serrano, A. (2014, July-September) Elementos epistemológicos e metodológicos da análise sociológica do discurso: Abrindo possibilidades para os estudos organizacionais. Organizações \& Sociedade - O\&S, 21(70), 509-536. Retrieved from https://portalseer.ufba.br/ index.php/revistaoes/article/view/11380/8210

Godoi, C. K., Mastella, A. S., \& Uchôa, A. G. F. (2018, JanuaryApril). Integração metodológica entre grupo de discussão e análise sociológica do discurso: Um caso exemplificador sobre o discurso feminino acerca do consumo da beleza. Revista Eletrônica de Administração - REAd, 34(1), 30-60. doi: 10.1590/1413-2311.180.69478

Godoi, C. K., \& Uchôa, A. G. F. (2019, October-December) Metodologia de Análise Sociológica Discursivo-Imagética: Possibilidades aos estudos organizacionais. Organizações \& Socie dade-O\&S, 26(91), 776-794. doi: 10.1590/1984-9260918

Gordo,A.; \& Serrano, A. (2008) Estrategias y prácticas cualitativas de investigación social. Madrid: Pearson Prentice Hall.

Ibáñez, J. (2003) Más allá de la sociología: el grupo de discusión: teoría y crítica. 5. ed. Madrid: Sieglo Veintiuno.

Mastella, A. D. (2015). O discurso feminino sobre o consumo de beleza na sociedade pós-moderna (Tese de Doutorado em Administração e Turismo, Universidade do Vale do Itajaí [UNIVALI], Biguaçu, SC).

Ortí, A. (1986). La apertura y el enfoque cualitativo o estructural: La entrevista abierta semidirectiva y la discusión de grupo. In M. García, J. Ibañez, \& F. Alvira, (Comps.), El análisis de la realidad social: Métodos y técnicas de investigación (pp. 189. 222). Madrid, España: Alianza.

Ortí, A. (2010). La apertura y el enfoque cualitativo o estructural: La entrevista abierta semidirectiva y la discusión de grupo. In M. García, J. Ibañez, \& F. Alvira (Orgs.), El análisis del realidad social: Métodos y técnicas de investigación (pp. 153-186). Madrid, España: Alianza.
Ortí,A. (2014) Encuestación cualitativa y práxis socioinstitucional: De la configuración de subjetividades sociales a la de discursos virtuales. Arxius de Ciències Socials, (31), 27-56. Retrieved from http://hdl.handle.net/10550/44309

Ruiz Ruiz, J. (2009). Análisis sociológico del discurso: Métodos y lógicas. Forum: Qualitative Social Research, 10(2). Retrieved from https://www.qualitative-research.net/index.php/fqs/ article/view/1298/2882

Ruiz Ruiz, J (2014). El discurso implícito: Aportaciones para um análisis sociológico. Reis - Revista Española de Investigaciones Sociológicas, (146), 171-190. DOI: https://doi. org/10.5477/cis/reis.146.171

Serrano, A. (2008). El análisis de materiales visuales en la investigación social: El caso de la publicidad. In A. Gordo, \& A. Serrano, Estrategias y práticas cualitativas de investigación social (pp. 245-286). Madrid, España: Pearson Prentice Hall.

Soares, J. R. R., \& Godoi, C. K. (2017). A metodologia da análise sociológica do discurso em estudos turísticos: 0 processo de transformação da imagem turística e sua relação com a lealdade. Revista de Turismo y Patrimonio Cultural, 15(1), 245 260. doi: 10.25145/j.pasos.2017.15.015

Triviños, A. N. S. (2008). Introdução à pesquisa em ciências sociais: A pesquisa qualitativa em educação. São Paulo, SP: Atlas.

Uchôa, A. G. F. (2017). A relação líder-liderado analisada sob o olhar da abordagem crítica da liderança e compreendida a partir da análise sociológica discursivo-imagética: Um estudo etnográfico em um campus universitário italiano (Tese de Doutorado em Administração e Turismo, Universidade do Vale do Itajaí [UNIVALI], Biguaçu, SC).

\section{AUTHORS CONTRIBUTION}

Katiuscia Schiemer Vargas worked on the conceptualization and theoretical-methodological approach, conducted the theoretical review and coordinated data collection. Data analysis was performed by Katiuscia Schiemer Vargas and Gilnei Luiz de Moura. The two authors, Katiuscia Schiemer Vargas and Gilnei Luiz de Moura worked together in the writing and final revision of the manuscript. 